\title{
Assessing Land-use Suitability of Existing Inclusionary Zoning Projects in the Australian Capital Territory
}

\author{
Shuangshuang Zheng \\ The University of Queensland, Australia \\ Thomas Sigler \\ The University of Queensland, Australia
}

\begin{abstract}
Inclusionary Zoning (IZ) is a land-use planning initiative undertaken by governments that either mandates or provides voluntary incentives to achieve a proportion of affordable housing in a development project. This research aims to assess the land-use suitability of the current IZ projects in the Australian Capital Territory (ACT) by comparing them with IZ land-use suitability study findings. A multi-criteria IZ land-use suitability analysis is conducted first to understand the desirable $I Z$ land features while considering sustainable development objectives. Four criteria are selected, including socioeconomic integration, access to jobs, access to public transport, access to green space, and compliance with zoning rules. Results indicate a relatively low suitability of current $I Z$ regimes. We conclude that the assessed low suitability across different $I Z$ projects is driven by the current market-based affordable housing provision approach, which highly relies on the private sector. Nevertheless, the research recognises the need for improving $I Z$ in the ACT through greater collaboration between state government, the federal government, and the property sector.
\end{abstract}

Key words: Inclusionary zoning, affordable housing policy, planning, socioeconomic integration, land-use suitability

\section{Introduction}

As a land-use planning tool, Inclusionary Zoning (IZ) has been widely adopted by developed countries to provide adequate affordable housing. In Australia, this planning initiative has been successfully implemented in South Australia (SA), New South Wales (NSW), and the Australian Capital Territory (ACT) (AHURI 2017). Despite IZ helping states establish a relatively large number of affordable housing units, limited research has been conducted to assess the quality of current IZ projects.Moving forward, it is critical to increase the affordable housing supply to meet the risingdemand while achieving sustainable development goals.

In this paper, we use ACT as a case study site to assess the land-use suitability of current IZ projects, and to identify potential bulwarks to achieving adequate outcomes. Additionally, three secondary questions will be discussed before answering the overarching research question. First, the number and location of current IZ projects inthe ACT. Second, the land-use characteristics and affordability of current IZ projects. Third, the suitable land for IZ land-use purposes in the ACT region by considering sustainable development goals. 


\section{Land-use planning and affordable housing provision in a market-based system}

The interaction between land use planning and the housing market is multi- dimensional in that it impacts both housing supply and demand dynamics (White \& Allmendinger 2003; Calder 2017; Murdoch \& Abram 2017). On the one hand, planning as a form of government intervention in the private market imposes additional constraints on the development sectors, which causes higher housing costs and associated housing prices accordingly. Libertarian thinkers in particular lament the supply-limiting measures that stringent planning imposes (Glaeser 2014). On the other hand, planning is a necessary intervention to minimize negative development externalities, which would otherwise harm the public good. More generally, the land-use planning tools contribute to a healthy housing market while generating social benefits (Oxley 2004; Evans 2008). Despite this complex interface, land use planning tools, such as zoning, have been adopted to enhance anticipated development outcomes or minimize undesirable externalities worldwide. Among those planning objectives, affordable housing provisions is one of them.

Affordable housing provides low-income or middle-income households access to adequate housing with additional assistance, and it applies to both owner-occupied and rental housing in Australia (Milligan et al. 2004). The motivation for providing affordable housing is related to the housing affordability issue, which is expressed as a unique social and material experience perceived by individual households when considering the cost of house purchase or rent (Stone 2006). It is often measured by the ratio of housing expenditure to household incomes (Thomas 2016). However, non- financial considerations, such as quality and location trade-offs, are often overlooked when assessing housing affordability issues (Rowley 2012). In the past decades, the disproportional increase between house prices and wealth accumulation has caused significant housing affordability issues around the world (Wetzstein 2017), a problem that is particularly acute in Australia (Worthington 2012). Nevertheless, the provision of affordable housing has been recognised as an essential part of the public welfare system; reflected in governments' housing and planning strategies.

Australia's planning policy has experienced several major shifts over time, and its planning trajectory has increasingly assumed a neoliberal pathway with an increased emphasis on a market-based form of government intervention (Gurran \& Whitehead 2011). Neoliberalism prevails in Australia's planning system across all three levels of government, which has impacted affordable housing provision strategies to a certain degree. Governments rely heavily on the private sectors to provide affordable housing for low or moderate-income households (Beer et al. 2007), with an ever-weaker public role in housing provision since the 1980s (Gurran et al. 2008). In addition, the rationale of planning policy design for affordable housing is to minimize adverse impacts onhousing markets, improve planning efficiency, and diversify the types of housing output. However, this clashes with the remit of governments to induce housing supply, as they do not intend to add an extra constraint on the developers due to a worry of discouraging the overall housing supply (Gurran \& Whitehead 2011).

The shifted policy emphasis of addressing affordable housing supply through private sectors has caused two primary concerns. Firstly, market-driven planning mechanisms coupled with other competing planning policies, such as urban containment and urban consolidation, have portrayed a paradoxical planning scene being debated extensively (e.g., Dodson 2010). Secondly, there is limited evidence to support the notion that an improved planning process can assist the supply of 
affordable housing through private sectors (Gurran \& Phibbs 2015). In this case, the planning tools that contrary to the planning mainstream, such as inclusionary zoning, are worthy of further investigation.

\section{Inclusionary zoning policies}

As a type of land-use planning tool, IZ still emphasizes market-based affordable housing provision. However, IZ differs from traditional planning tools by pushing the delivery of dwellings deemed to be affordable onto the developer. Inclusionary zoning was first introduced in Virginia, USA in 1971 to increase affordable housing supplies and promote socioeconomic integration (Ellickson 1980). Thus, governments often require the $I Z$ programs to be in the market-rate housing neighbourhoods with high human development opportunities; typically, more socioeconomically advanced communities (Tuller 2018). This social-mix strategy is highly relevant to the 'exclusionary zoning' historical context in the US, which prohibits low- or moderateincome families from moving into affluent areas by regulating minimum lot sizes and regulating housing density (Kautz 2001). IZ policy then gained popularity rapidly nationwide taking place in various forms that were either mandatory or voluntary in the following decades (Thaden \& Wang 2017). The mandatory IZ is more dominantly featured by requiring a proportion of affordable housing through on-site or off-site developments, and or by paying in-lieu fees that go into the government's affordable housing funds. The voluntary incentives intend to encourage the private provision of affordable housing by introducing various incentives, including density bonuses, zoning variance, fee reductions, and waivers.

Most jurisdictions utilize median household income as a benchmark to assess the eligibility of affordable housing applicants, and IZ often does not target the lowest income profile families (InclusionaryHousing.Org 2019). Commonly, it is packaged as a part of a jurisdiction's social or affordable housing strategy package, which is customised to the local socioeconomic conditions (Hickey et al. 2014). To date, there are more than 500 jurisdictions across 28 states in the US that implemented IZ policies (Sturtevant 2016). Following this lead, a wide range of countries including Australia, Canada, and New Zealand have adopted the IZ strategy to a varied extend (Mah 2009; Gurran et al. 2018; Fernandez \& Martin 2020). Table 1 is a summary of research findings that relevant to IZ policies.

\begin{tabular}{|c|c|}
\hline Category & Description \\
\hline Goal & Socioeconomic integration, providing adequate affordable housing \\
\hline \multirow[t]{9}{*}{ Forms } & Mandatory: \\
\hline & - Provide affordable housing through on-site development \\
\hline & - Provide off-site affordable housing \\
\hline & - Pay in-lieu fees that can be used to support affordable housing in other forms \\
\hline & Voluntary/provide incentive: \\
\hline & - Density bonuses \\
\hline & - Zoning variances \\
\hline & - Fee reductions \\
\hline & - Waivers \\
\hline \multirow[t]{2}{*}{ Merits } & - Affordable housing productivity \\
\hline & $\begin{array}{l}\text { - Social integration and induced social benefits, such as improved physical and } \\
\text { mental health, reduction in crime and violence }\end{array}$ \\
\hline \multirow[t]{3}{*}{ Criticisms } & - Not meeting affordable housing need \\
\hline & - $\quad$ Developers may walk away from places with IZ policies \\
\hline & - Adverse effects on market-rate housings \\
\hline
\end{tabular}




\begin{tabular}{lll}
\hline Characteristics & - & Great variation in policy and program design \\
& - & Vary in enforcement mechanism: such as the targeted participation, \\
& applicable development types, and geographic scope \\
\hline Critical issues & - & Long-term affordability of IZ housing \\
& - Creative use of different funding models \\
& - & The need for governments' long-term commitment to cater communities' need \\
& & and economic conditions \\
\hline IZ & - & Poverty rate \\
performance & - & School performance \\
indicators & - & Racial diversity \\
\hline
\end{tabular}

Table 1: Summary of $\mathrm{IZ}$ policies

In Australia, the introduction of IZ was in response to the shortage of affordable housing caused by rising housing prices, which was fuelled by the call for more proactive land-use planning strategies (Beer et al. 2007; Austin et al. 2014). Despite the divided viewpoints towards IZ amongst different states, this planning initiative has obtained legal status in South Australia, New South Wales, and the Australian Capital Territory (AHURI 2017). A comparison of IZ policies and implementation mechanisms within these three jurisdictions is provided in Table 2. Meanwhile, other states including Queensland, Victoria, and Western Australia have attempted or piloted IZ relevant policies to a varying degrees (National Shelter 2019). At the time of introduction, this was achieved through Voluntary Planning Agreements in inner-city urban revitalization projects of City West and Green Square in Sydney; dating back to the late 1990s (Williams 2000). The ACT and SA have pushed mandatory mechanisms in the following decades, which specifies an affordable housing component target (see Table2) within a development program (AHURI 2017). Overall, IZ has drawn upon both proponents and criticism broadly in Australia.

\begin{tabular}{llllll}
\hline $\begin{array}{l}\text { Statel } \\
\text { Territory }\end{array}$ & Status & Requirement & Incentives & Areas & $\begin{array}{l}\text { Rental/ } \\
\text { ownership }\end{array}$ \\
\hline SA & Legislated & $\begin{array}{l}15 \% \text { target for } \\
\text { residential } \\
\text { zones }\end{array}$ & $\begin{array}{l}\text { Incentives and } \\
\text { concessions to } \\
\text { support achievement } \\
\text { of target }\end{array}$ & $\begin{array}{l}\text { New } \\
\text { developments }\end{array}$ & $\begin{array}{l}\text { Mainly } \\
\text { improve } \\
\text { ownership }\end{array}$ \\
\hline ACT & Legislated & $\begin{array}{l}15-25 \% \\
\text { target of new } \\
\text { land release }\end{array}$ & $\begin{array}{l}\text { Applying to } \\
\text { affordable home } \\
\text { ownership }\end{array}$ & General & Both \\
\hline NSW & Occasional & $\begin{array}{l}\text { In designated } \\
\text { parts of inner } \\
\text { Sydney }\end{array}$ & $\begin{array}{l}\text { State-wide policy, to } \\
\text { encourage affordable } \\
\text { rental housing }\end{array}$ & $\begin{array}{l}\text { Specific to local } \\
\text { government } \\
\text { areas }\end{array}$ & Rental \\
\hline
\end{tabular}

Table 2: IZ policy and implementation mechanisms in Australia

Note. Adapted from https://shelter.org.au/site/wp-content/uploads/190325-Inclusionary-Zoning-Report-V6Final-1.pdf. Copyright by National Shelter (2021).

Inclusionary zoning delivery: the quantity and quality of affordable housing

Builders (NAHB) in the US claim that the IZ policies produce far fewer affordable housing units compared to other affordable housing programs such as low-income housing tax credit (NAHB 2019). A similar view is held by Amirtahmasebi et al. (2015), who claim that affordable housing offered under $\mathrm{IZ}$ policies is not meeting up with the needs for affordable housing in the US. This inadequacy of $I Z$ partially subjects to its policy nature, which has a limited capacity to overcome the fundamental planning barriers to low-cost housing (HUD 2005). Developers disincentivized by 
IZ may choose to walk away from the jurisdictions with such policies and look for development location alternatives (Ellickson 1980). Whereas numerous studies found evidence of underestimated affordable housing productions of IZ policies. For example, Dawkins et al. (2016) studied the Moderately Priced Dwelling Unit (MPDU) program in Montgomery County, Maryland, and they found that IZ helped to establish a significant number of affordable homes within the area. Also, Mukhija et al. (2010) argued that IZ, especially the mandatory IZ policies, delivered more affordable housing than other affordable housing programs through an investigation of Los Angeles and Orange Counties. In Australia, Gurran et al. (2018) found that IZ yielding affordable housing constitutes a relatively large proportion of the overall housing supply. More specifically, South Australia adds a total number of 5,485 affordable housing units under the IZ strategies from 2005 to 2015 , taking 17 percent of the region's overall housing supply.

The difficulty of obtaining accurate affordable housing delivered by the IZ across the US has been observed due to the multiple ways of IZ implementation (Thaden \& Wang 2017). Nevertheless, the estimated affordable housing units produced by $I Z$ range from an estimated 150,000 to 173,000 in the US (Sturtevant 2016), with considerable variation between cities and regions.

Current research on affordable housing quality delivered by IZ attracts less attention than the affordable housing production issues. Predominantly, the assessments of IZ programs' quality consider their ability to achieve socioeconomic and racial integration. To be specific, Kontokosta (2014) sees a robust association between the demographic characteristics of the IZ location and the level of socioeconomic integration. He argues that the risk of undermining the effectiveness of IZ programs exists when they are misallocated to a low socioeconomic status community. Rothwell (2012) also emphasises the importance of offering IZ affordable housing in socially advantaged neighbourhoods. This is because IZ offers a chance for children from disadvantaged backgrounds access to better schools and adults are afforded better transport throughaccess to transit corridors. For example, American Planning Association Housing Initiative supports the IZ housing units to be located along the transit corridors (CMAP2021), which is regarded as a "fair share" approach providing residents better access to jobs and public services. In the report prepared by the Chicago Metropolitan Agency for Planning, they conclude that IZ with proximity to jobs and mobility services can achieve a better policy outcome (CMAP 2008), owing to that the decreased housing costs would be offset by the increased transportation costs if the distance between affordable housing and employment exceeds a range of 12 to 15 miles (Lipman 2006).

Nevertheless, assessments of the quality of the current IZ programs are largely absent, especially with a consideration of a full spectrum of social, economic, and environmental dimensions. This paper intends to fill in this gap by comparing the existing $I Z$ programs with a land-use suitability study result by using an example of ACT. 


\section{Study Area: The Australian Capital Territory}

The selected study area is the Australian Capital Territory (ACT), which is a federally administered territory in which the Australian capital of Canberra is located. Neighbourhood units for assessing IZ quality are adopted from ABS SA2 (see Figure1).

Figure 1: Study area - ACT and SA2s

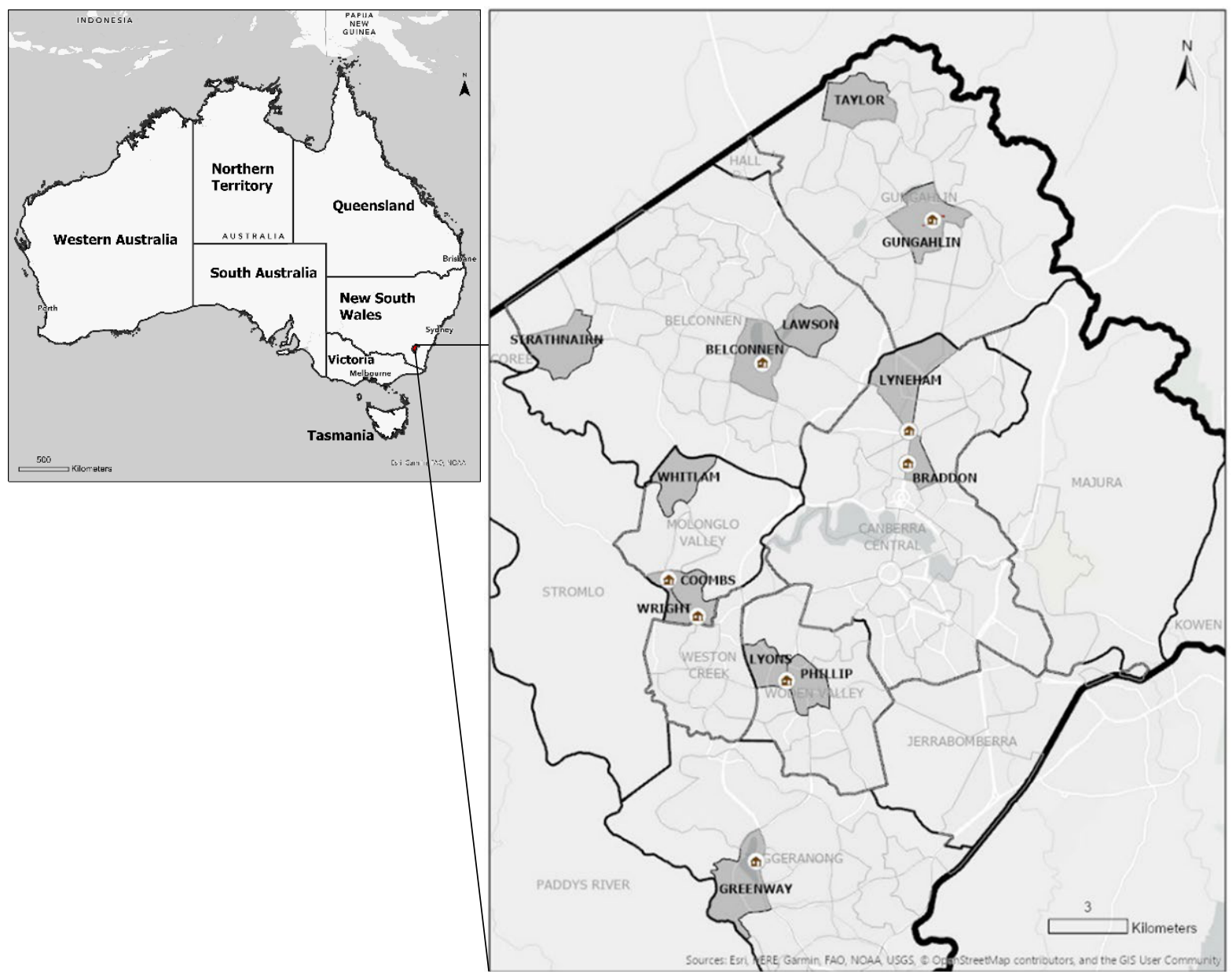

The IZ mechanism was first adopted by the ACT government in 2007 through the Affordable Housing Action Plan (EPSDD 2007). The new housing strategy introduced in 2018 has also incorporated IZ through a form of housing targets (ACT Government 2018). One of the major aims of housing targets is to increase the supply of affordable private rental properties and affordable home ownership (ACT Government 2020). Based on an Inclusionary Zoning report generated by the National Shelter (2019), ACT has a more aggressive affordable housing target at a range of 15-25 percent of newly released land compared to NSW and SA. Also, it is the only state implementing a mandatory $I Z$ approach in both urban renewal programs and the development of new suburbs (see Table 2). According to the ACT government's report, more than 1,300 affordable housing units have been established through the $I Z$ program in the past three years (see Table 3). "Suburban Land Agency" and the "City Renewal Authority" are two major participants in the determination of affordable housing targets and the delivery of those targets. They are responsible for the different projects located in outer suburbs and the urban renewal precinct, respectively (ACT Government 2018). It is worth noting that the unique nature of development in the ACT by the Suburban Land Agency, which is a statutory authority that does land supply (ACT Government 2018). However, their function is typically carried out by private land developers in other states in Australia; development applications are often launched by private sector developers and assessed by the government, rather than doing it themselves. Nevertheless, since the implementation of the IZ strategy, there is minor variation between the 
annual targets and actual deliveries. As Table 3 indicates, previous two years have failed to achieve its targets while the latest year has significantly exceeded this pre-determined goal. Additionally, all affordable homes were established outside the urban renewal precinct.

\begin{tabular}{|c|c|c|c|c|c|c|c|}
\hline \multirow{2}{*}{$\begin{array}{l}\text { Project } \\
\text { context and } \\
\text { area }\end{array}$} & \multirow{2}{*}{ Suburb } & \multicolumn{2}{|c|}{ 2017-18 } & \multicolumn{2}{|l|}{ 2018-19 } & \multicolumn{2}{|c|}{$2019-20$} \\
\hline & & Target & Actual & Target & Actual & Target & Actual \\
\hline \multirow{3}{*}{$\begin{array}{l}\text { Urban renewal } \\
\text { precinct }\end{array}$} & City & - & - & - & - & 60 & 0 \\
\hline & Braddon & - & - & - & - & - & 80 \\
\hline & Lyneham & - & - & 50 & 0 & - & 50 \\
\hline \multirow{2}{*}{$\begin{array}{l}\text { Urban renewal } \\
\text { in areas } \\
\text { outside an } \\
\text { urban precinct }\end{array}$} & Lawson & 39 & 80 & - & - & - & - \\
\hline & Greenway & 28 & 40 & - & - & - & - \\
\hline \multirow{10}{*}{$\begin{array}{l}\text { Development of } \\
\text { a new suburb }\end{array}$} & Taylor & 88 & 99 & 139 & 146 & 6 & 68 \\
\hline & $\begin{array}{l}\text { North } \\
\text { Wright }\end{array}$ & 53 & 32 & - & - & - & - \\
\hline & Wright & - & - & 56 & 56 & - & - \\
\hline & Coombs & 67 & 37 & 80 & 82 & 96 & 96 \\
\hline & Whitlam & - & - & 44 & 0 & 60 & 105 \\
\hline & Strathnairn & 78 & 0 & 60 & 2 & 25 & 0 \\
\hline & Belconnen & - & - & 3 & 0 & 87 & 87 \\
\hline & Gungahlin & - & - & 10 & 10 & 80 & 132 \\
\hline & Lyons & - & - & 70 & 70 & - & - \\
\hline & Phillip & - & - & - & - & 74 & 74 \\
\hline total & & 353 & 288 & 512 & 366 & 488 & 692 \\
\hline
\end{tabular}

Table 3: Summary of IZ targets and actual deliveries in ACT

Note. Data from “Suburban Land Agency Annual Report (2018-2020)" by ACT Government (20182020).

Although not strictly an IZ scheme, the ACT Housing Strategy (ACT Government 2018) does incorporate IZ policy mechanism with a certain proportion of social and affordable housing targets in its annual indicative land release program. Also, the objective of creating socioeconomic integration is reflected in the aims and functions of the key affordable housing delivery agency: Suburban land agency. Specifically, the agency will ensure a mixture of public and private housing choices in new suburbs to support social inclusion. In this case, the study recognizes the IZ policy nature of ACT's affordable housing strategies, which is in line with the Australian Housing and Urban Research Institute's research findings (AHURI 2017). IZ policy is identified as an indicator for the goals of "Grow the supply of affordable private rental properties" (goal 4B) and "Provide more affordable homes for purchase" (goal 5A) under the ACT Housing Strategy 2018. A literature review of IZ is underway in the ACT government (ACT Government 2020).

The affordable housing delivered by the IZ program is relatively affordable in general. As shown in Table 4, the affordable housing price in the last three years is approximately $60 \%$ of the average general housing price city-wide, with an increasing affordability trend. Whereas the gap between affordable housing prices and general residential housing prices is likely to vary amongst different neighbourhoods. 


\begin{tabular}{|c|c|c|c|c|}
\hline Year & $\begin{array}{c}\text { Affordable } \\
\text { housing } \\
<80 \mathrm{~m}^{2}\end{array}$ & $\begin{array}{c}\text { Affordable } \\
\text { housing } \\
80 m^{2}-105 m^{2}\end{array}$ & $\begin{array}{c}\text { Affordable } \\
\text { housing } \\
>105 \mathrm{~m}^{2}\end{array}$ & Normal residential dwellings (ACT) \\
\hline 2017-18 & $\$ 323,000$ & $\$ 374,000$ & $\$ 425,000$ & $\$ 676,700$ \\
\hline 2018-19 & $\$ 330,000$ & $\$ 381,000$ & $\$ 434,000$ & $\$ 680,000$ \\
\hline 2019-20 & $\$ 330,000$ & $\$ 381,000$ & $\$ 434,000$ & $\$ 727,100$ \\
\hline
\end{tabular}

Table 4: Maximum affordable housing price by dwelling size vs mean normal housing price in ACT

Note. Maximum affordable housing price from https://www.planning.act.gov.au/urban- renewal/affordablehousing/affordable-home-purchase. Copyright by ACT Government (2021). Datafor mean normal housing price from ABS (2021).

\section{Data and Methodology}

This research adopts a GIS-based land-use suitability analysis method, particularly a Multi-criteria Evaluation (MCE) approach, to select potential land catering for future IZland purposes in the ACT. The method is used to identify suitable land for certain purposes amongst land alternatives based on selected criteria (Nyerges et al. 2010). It has been widely used in the planning decisionmaking process, which incorporates both quantitative and qualitative data (Malczewski 2004). For example, Liu et al. (2014) adopted a land-use suitability analysis to identify urban development opportunities in Beijing. Javadian et al. (2011) conducted a land-use suitability analysis in Tehran by inserting sustainable development considerations.

In this research, the adopted criteria are divided into two categories: opportunity criteria and constraint criteria. Opportunity criteria are positively associated with desirable IZ housing outcomes, while constraint criteria restrict IZ land within a certain geographical area. Nevertheless, the selection of IZ land-use suitability criteria considers two broad aspects: policy nature and sustainable development goals (see Table 5).

\begin{tabular}{|c|c|c|}
\hline Selection rationale & Description & Applicable criteria \\
\hline IZ policy nature & $\begin{array}{l}\text { Aim of policy: promote socioeconomic } \\
\text { integration }\end{array}$ & - Socioeconomic integration \\
\hline \multirow{3}{*}{$\begin{array}{l}\text { Sustainable } \\
\text { development goal }\end{array}$} & $\begin{array}{l}\text { Social benefits: promote human wellbeing } \\
\text { and human development opportunities }\end{array}$ & $\begin{array}{ll}\text { - } & \text { Socioeconomic integration } \\
\text { - } & \text { Public transport } \\
\text { - Job } \\
\text { - Green space }\end{array}$ \\
\hline & $\begin{array}{l}\text { Economic benefits: reduce costs and } \\
\text { maximize profits }\end{array}$ & $\begin{array}{l}\text { - Socioeconomic integration } \\
\text { - } \quad \text { Public transport } \\
\text { - Job }\end{array}$ \\
\hline & $\begin{array}{l}\text { Environmental benefits: minimise impact } \\
\text { on wildlife and natural vegetation; carbon } \\
\text { emission reduction }\end{array}$ & $\begin{array}{ll}\text { - } & \text { Public transport } \\
\text { - } & \text { Job } \\
\text { - Zoning }\end{array}$ \\
\hline
\end{tabular}

Table 5: Summary of selection rationale for IZ land-use suitability study 


\section{Socioeconomic integration criterion}

Socioeconomic integration is a primary consideration in the land-use suitability study, which is an inherent policy interest rooted in the IZ. The benefits of living in mixed-income communities for low-income households have been discussed widely, including improved mental health, opportunities for attending better schools, a safe community environment, and improved job opportunities (e.g., Levy et al. 2010; Ludwig et al. 2013). Thus, socioeconomically more advanced neighbourhoods are more favourable for the suitability study. In Australia, Socio-Economic Indexes for Areas (SEIFA) developed by the Australian Bureau of Statistics (ABS) are commonly used to understand a neighbourhood's socioeconomic status. Specifically, the Index of Relative Socioeconomic Disadvantage (IRSD) is adopted in this study to allocate suitability scores. It broadly refers to people's access to material and social resources and their ability to participate in society (ABS 2016). Generally, the communities wouldbe assigned with a lower IZ land suitability score if they are in the lower decile of IRSD, meaning a relatively lower socioeconomic status.

\section{Job criterion}

Although driving is a more popular mode of transport to work than walking in ACT, the job criterion is measured by walking distance instead of driving distance to promote carbon emission reduction under the sustainable development goals. Therefore, the maximum 12-15 miles driving distance between home and the workplace identified in the literature review is not applicable for this study. To understand the job distribution pattern in ACT, the research conducts a preliminary analysis of employment characteristics. It shows that the largest six employment sectors of the ACT are Public Administration and Safety, Professional, Scientific and Technical Services, Health care and Social Assistance, Education and Training, Accommodation and Food Services, and Retail Trade (ABS 2021). People working in the former four sectors are less likely to meet affordable housing application requirements since they generally receive higher salaries than other sectors. Therefore, the suitability study selects job centres of accommodation and food serviceclusters and retail clusters that broadly stand for commercial areas. Since these commercial areas are also the places where people enjoy day-to-day services, IZ families can have better access to services when locating IZ homes close to job centres. This added benefit contributes to an improved life quality, which is a highly relevant criterion of assessing housing quality in general (Zeng et al. 2019). Notwithstanding, the medium suitability score for job criterion uses a 0.5 -mile walking distance to predetermined job clusters, which is identified as the medium distance of walking trips among all US walkers (Yang \& Diez-Roux 2012).

\section{Public transport criterion}

Walking distance forms the basis of the public transport criterion, providing access to those without private vehicles. The underlying rationale covers social, environmental, and economic aspects, including the potential reduction of transportation costs, carbon emissions reduction, and improved mobility for low-income families without cars. Additionally, people are more likely to walk and gain walking-associated health benefits when dwellings are located within walking distance to a transit hub (ACT Government 2015). Although researchers and practitioners do not uniquely define the walkable distance, the general perception for planners is a 400-meter walking distance between residential dwellings and a bus station and double the distance for a train station (Kittelson \& Associates et al. 2003). In the ACT, the Government's active travel study report concluded that the medium walking distance from residential properties and a bus station is 260 meters, and $95 \%$ of households live within 500 to 750 meters of bus stops (ACT Government 
2015). Based on this report, ACT has relatively high walkability if only following walking distance to public transit criterion. However, transport mode would also impact people's choice of transit, some of which are less restricted in frequency and service alternatives (Mazzulla 2006). In this case, the suitability score allocated to the different stops would vary depending on their number of service modes and service routes on-site, while a unified 400-meter service area distance to all bus stops and an 800-meter service area distance to all rail stops are adopted.

\section{Green space criterion}

Green space, such as parks and recreational areas, can promote human health and well-being, which has been acknowledged widely. This benefit is often articulated into the walkable neighbourhood concept and reflected on the requirement of cooperating infrastructure provision and housing planning. One case is the Queensland government's mandatory requirement for housing subdivision; parks and open space are required within 400 meters of each part of a block when subdivision occurs (Property Council of Australia 2020), indicating the importance of locating residential properties nearby the existing green space. Furthermore, Sugiyama et al. (2010) highlight the significance of closeness and the quality of parks to attract more visits, and the maximum walking distance to a park with high amenities is approximately $1.6 \mathrm{~km}$. The quality of parks and recreational areas should be assessed and considered in the suitability study ideally. Notwithstanding, this study does not consider the quality of parks since proximity is a more dominant factor. It is possible to improve research quality by combining both factors for future studies. Overall, the suitability score is assumed to be the lowest when it exceeds the maximum of 800 - meter walking distance and is further up-scored with every 200 -meter interval.

\section{Zoning criterion}

The zoning criterion is a constraint criterion, which prevents the $\mathrm{IZ}$ projects from being allocated to non-residential land-use areas. This arrangement intends to minimize human disturbance on the wildlife and natural environment and reduce planning costsby avoiding any contravention of planning regulation. In the ACT, zoning rules are integrated into geographic data that can be accessed through ACT Government GeoHub, which specifies residential land-use zones: RZ1Suburban, RZ2 - SuburbanCore, RZ3 - Urban Residential, RZ4 - Medium Density Residential, and RZ5-High Density Residential (ACT Government 2008). The final IZ land allocation map would be confined within the existing residential land-use boundary.

A summary of suitability study results and selecting rationale for each criterion are outlined in Table 6. 


\begin{tabular}{|c|c|c|c|c|c|c|c|c|}
\hline & \multicolumn{7}{|c|}{ Suitability score } & \multirow[b]{2}{*}{ Rationale for selection } \\
\hline \multicolumn{2}{|r|}{ Criteria } & $\begin{array}{l}\text { Spatial } \\
\text { attribute }\end{array}$ & $\begin{array}{l}1 \\
\text { very } \\
\text { low }\end{array}$ & $\begin{array}{l}2 \\
\text { low }\end{array}$ & $\begin{array}{l}3 \\
\text { moderate }\end{array}$ & $\begin{array}{l}4 \\
\text { high }\end{array}$ & $\begin{array}{l}5 \\
\text { very high }\end{array}$ & \\
\hline \multirow{5}{*}{ Opportunity } & $\begin{array}{l}\text { Socioeconomic } \\
\text { integration }\end{array}$ & $\begin{array}{l}\text { Overlap with } \\
\text { IRSD- ranked } \\
\text { SA2 } \\
\text { neighbourh } \\
\text { oods }\end{array}$ & $\begin{array}{l}\text { Decile } \\
1-2\end{array}$ & $\begin{array}{l}\text { Decile } \\
3-4\end{array}$ & $\begin{array}{l}\text { Decile } \\
5-6\end{array}$ & $\begin{array}{l}\text { Decile } \\
7-8\end{array}$ & $\begin{array}{l}\text { Decile } \\
9-10\end{array}$ & $\begin{array}{l}\text { - } \quad \text { Aim of IZ policy: socioeconomic integration } \\
\text { - Social: Increase the chance to receive a better } \\
\text { education } \\
\text { - Social: Human wellbeing associated with a safe community } \\
\text { environment } \\
\text { - } \quad \text { Social: Human wellbeing due to improved jobopportunities } \\
\text { Economic: possible economic gains from improved job } \\
\text { - } \quad \text { Epportunities and less expenditure on transportation cost } \\
\end{array}$ \\
\hline & & Distance to & & $600-$ & $400-$ & $200-$ & & $\begin{array}{l}\text { walkability } \\
\text { - Social: Human wellbeing due to improved job }\end{array}$ \\
\hline & Job & $\begin{array}{l}\text { commercial } \\
\text { zones }\end{array}$ & $>=800 \mathrm{~m}$ & $800 \mathrm{~m}$ & $600 \mathrm{~m}$ & $400 \mathrm{~m}$ & $<=200 \mathrm{~m}$ & $\begin{array}{l}\text { opportunities and close to day-to-day services } \\
\text { Economic: possible economic gains from } \\
\text { improved job opportunities and less expenditure } \\
\text { on transportation cost }\end{array}$ \\
\hline & Public transport & $\begin{array}{l}\text { Service area } \\
\text { of a bus stop } \\
\text { and number } \\
\text { oftransport } \\
\text { services; } \\
\text { service area } \\
\text { of a rail stop }\end{array}$ & $\begin{array}{l}400 \mathrm{~m} \\
\text { service } \\
\text { area of } \\
\text { the restof } \\
\text { bus stops }\end{array}$ & $\begin{array}{l}400 \mathrm{~m} \\
\text { service area } \\
\text { of bus stops; } \\
\text { one } \\
\text { transport } \\
\text { service; two } \\
\text { to fiveroutes }\end{array}$ & $\begin{array}{l}400 \mathrm{~m} \\
\text { service area } \\
\text { of bus stops } \\
\text { with two } \\
\text { transport } \\
\text { service and } \\
\text { two to five } \\
\text { routes }\end{array}$ & $\begin{array}{l}400 \mathrm{~m} \\
\text { service area } \\
\text { of bus stops; } \\
\text { two } \\
\text { transport } \\
\text { service; six } \\
\text { to ten routes }\end{array}$ & $\begin{array}{l}400 \mathrm{~m} \text { service area } \\
\text { of bus stops; two } \\
\text { or three transport } \\
\text { service; more than } \\
10 \text { routes; } \\
800 \text { meters } \\
\text { service area of } \\
\text { railway transits }\end{array}$ & $\begin{array}{l}\text { - Social: Human wellbeing due to reduced stress on long- } \\
\text { distance travel or traffic congestion } \\
\text { - Social: Human wellbeing due to improved mobility(especially } \\
\text { for low-income families without cars) } \\
\text { - Environmental: Carbon emission reduction by encouraging } \\
\text { walking and using public transport instead of driving } \\
\text { Economic: possible economic gains from less expenditure on } \\
\text { transportation cost }\end{array}$ \\
\hline & Green space & $\begin{array}{l}\text { Distance to } \\
\text { parks and } \\
\text { recreational } \\
\text { areas }\end{array}$ & $>=800 \mathrm{~m}$ & $600-800 \mathrm{~m}$ & $400-600 \mathrm{~m}$ & $200-400 \mathrm{~m}$ & $<=200 \mathrm{~m}$ & $\begin{array}{l}\text { - Social: Human wellbeing due to improved } \\
\text { walkability and being close to nature }\end{array}$ \\
\hline
\end{tabular}

\section{Table 6: IZ land-use suitability study result}




\section{Spatial Analysis}

To visually demonstrate the land-use suitability results, the study utilizes a GIS mapping tool. GIS mapping draws various layers separately under each criterion, anda final IZ land allocation map is generated by aggregating all layers under a Weighted Linear Combination Decision Rule (WLC). The WLC is established upon the ranking of each criterion, which uses the formula below (Nyerges et al. 2010):

$$
W W=\frac{n n-m i j+1}{\sum_{k=1}^{m}\left(n n-w_{k k}+1\right)}
$$

Where $w w_{j j}$ is the numerical weights of the criterion $j, n$ is the number of total criteria, and $r r_{j j}$ is the ranking order of the criterion $j$.

\begin{tabular}{lll}
\hline Criteria & Rank & Weight \\
\hline Socioeconomic integration & 1 & $40 \%$ \\
\hline Better access to jobs & 3 & $20 \%$ \\
\hline Better access to public transits & 2 & $30 \%$ \\
\hline Better access to parks and recreational areas & 4 & $10 \%$ \\
\hline
\end{tabular}

Table 7: Rank of each criterion

The rank for each criterion is based on the selection rationale; criterion with more selection attributes is ranked higher. For example, socioeconomic integration ranks first with the most identified rationales, including the requirement of IZ policy and identified social and economic benefits. By applying this ranking approach, a completed ranking is shown in Table 7. Finally, the land with a higher appraisal score calculated under the WLC decision rule is the land suited for future IZ land purposes. To be noticed, there will be no manual data transformation in this step since ArcGIS has implemented the WLC decision rule in its overlay function.

\section{Data collection}

Three types of data are collected in the GIS mapping process. Specifically, the mapping of current IZ projects utilizes the location information of the affordable housing projects according to Suburban Land Agency's annual report (ACT Government 2018; ACT Government 2019; ACT Government 2020), and the planning map from the Territory Plan 2008 (ACT Government 2008) is used as a base map. There are several IZ projects' locations are not provided, particularly those from 2017 to 2018, the GIS mapping only illustrates IZ projects with available location data, and it shows the neighbourhoods' (SA2) location instead for those without sufficient data (see Figure 1). The geospatial data are collected through governmental geospatial data channels, such as ABS, ACT Government Open Data, and ACT Government GeoHub. Finally, two types of data are used for classifying criteria data. The IRSD adopted from the ABS is used to assess the socioeconomic status of communities. As for the transits' service quality classification purpose, the study uses the types of transit modes and the number of transport services available on-site, which can be accessed through Transport Canberra (2020). 


\section{Findings: Low Land-use Suitability for Current IZ Projects}

The study finds low suitability of IZ projects in ACT relative to its ability to achieve five selected criteria. Particularly, few IZ projects havebeen allocated in high socioeconomic neighbourhoods and new suburbs with IZ projects have low accessibility to the public transport system.

ACT's population centres are in outer suburbs instead of Canberra central area due to its special political status. Specifically, Canberra central areas are dedicated to multiple designated purposes prohibiting private developments. The population centres are connected by frequent bus services and railway lines. Overall, ACT is significantly less populated than most states or territories in Australia with a total population of 431,500 by the end of 2020 (ABS 2021). Suburbs are characterized by low-density detached houses, and greenfield development is a common practice in Australia to cater to population growth.

According to the socioeconomic integration mapping result (see Figure 2), most IZ dwellings are not allocated in socioeconomically advanced communities since only two of $13 \mathrm{IZ}$ neighbourhoods are in the highest IRSD deciles. In addition, three new IZ suburbs, Taylor, Strathnairn, and Whitlam, were established on the urban periphery without sufficient demographic data to assess its current socioeconomic condition. There is also associated low accessibility to public transit for $I Z$ housings in the three new suburbs as shown in the public transport mapping result (see Figure 3 ). While IZ housings offered in existing suburbs are identified with relatively higher public transit accessibility being located along the primary transit corridors. Notably, Gungahlin, Lyneham, and Braddon have a "Very High" public transit suitability with both rail and rapid bus services on-site. Job criterion mapping result illustrates less variance since jobs are distributed in ACT broadly and dispersedly (See Figure 4). However, Gungahlin, Lyneham, Braddon, Belconnen, Phillip, and Greenway are identified with larger commercial areas, which may be equipped with more job opportunities. Similarly, the green space mapping result indicates that the existing residential areas generally have high accessibility to green spaces (see Figure 5). In this case, the suitability study result under this criterion does not vary significantly among different IZ suburbs. Although the constraint criterion of residential land uses does not intend to rate suitability levels among different levels of living densities, the research found that higher-density areas gained more popularity in general based on the distribution of current IZ homes (see Figure 6).

The final IZ land allocation map is demonstrated by Figure 7, which combines five individual criterion layers. New suburbs, Taylor, Strathairn, Whitlam, and most parts of Lawson fall into the very-low suitability land category due to a compound effect of five criteria. Most of the land in Gungahlin, Belconnen, and Greenway is found at a very low IZ land suitability score, which may relate to the residential zoning constraint.Comparatively, Lyneham, Braddon, Coombs, Wright, Lyons, and Phillip have larger areas that are identified with higher IZ land suitability scores. In conclusion, IZ affording housing units in Gungahlin and Braddon are evaluated with the highest suitability score, followed by IZ homes in Coombs and Wright. IZ housings are not allocated to the land with high suitability scores in general. 
Figure 2: Socioeconomic integration mapping result

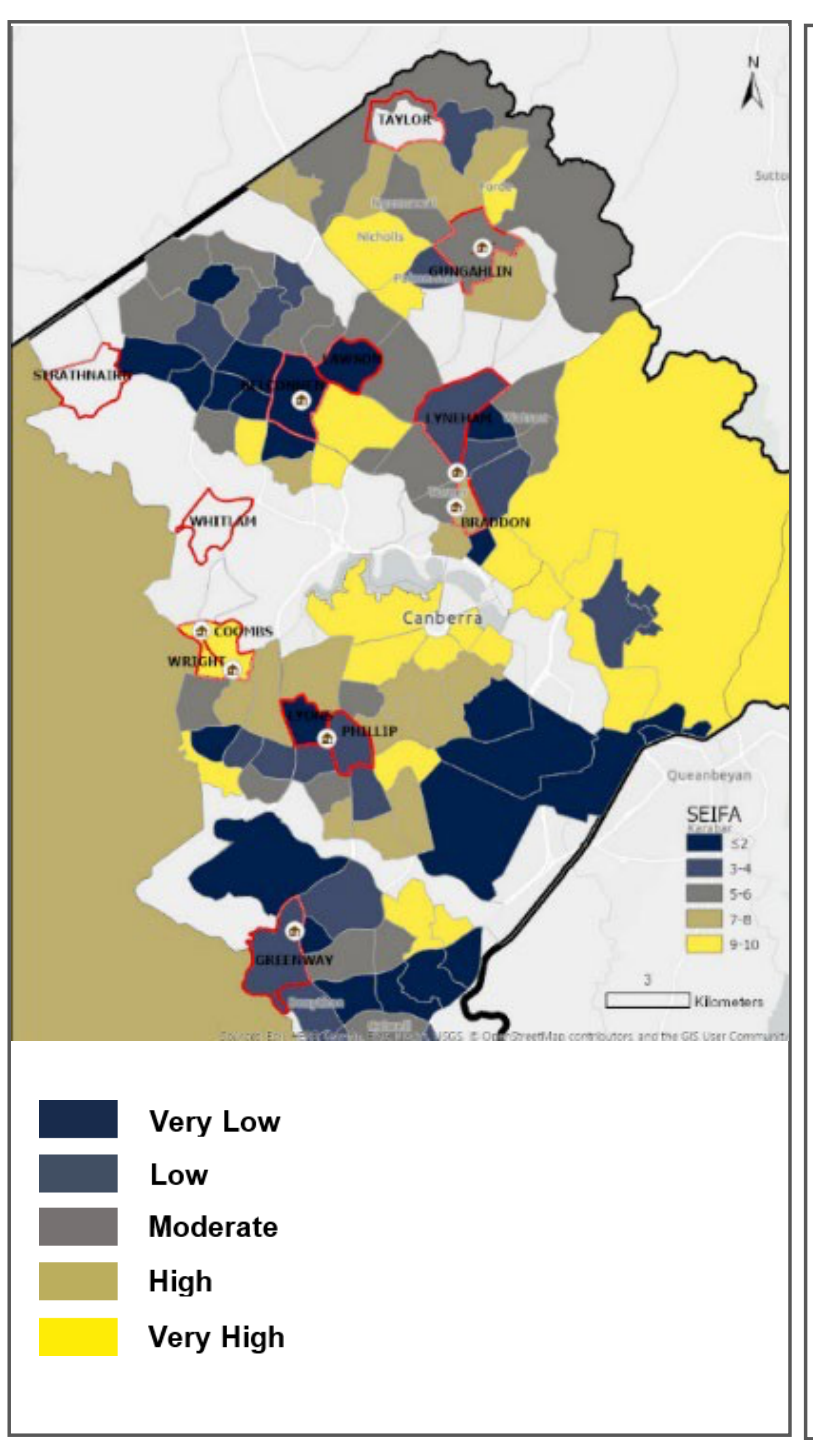

Figure 3: Public transport mapping result

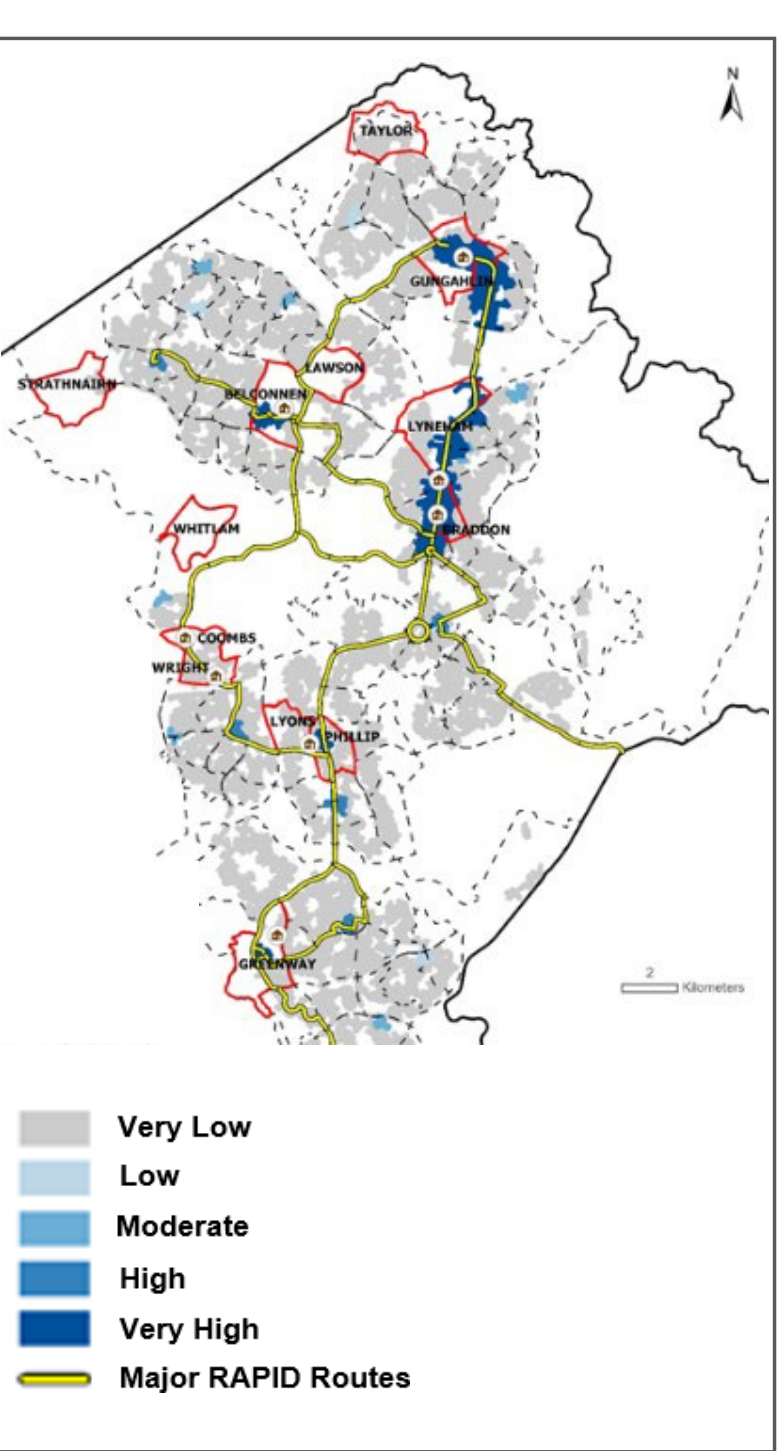

Figure 4: Job mapping result

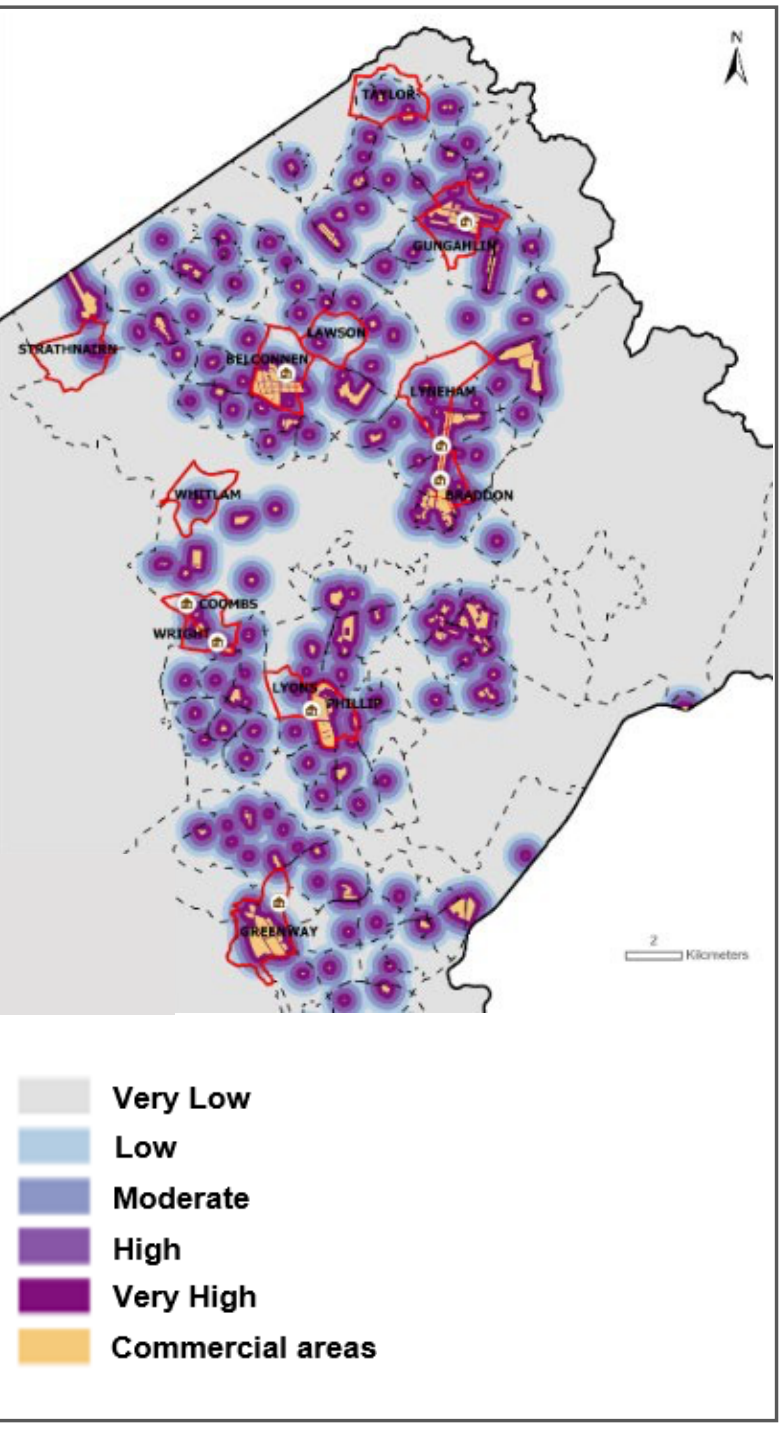


Figure 5: Green space mapping result

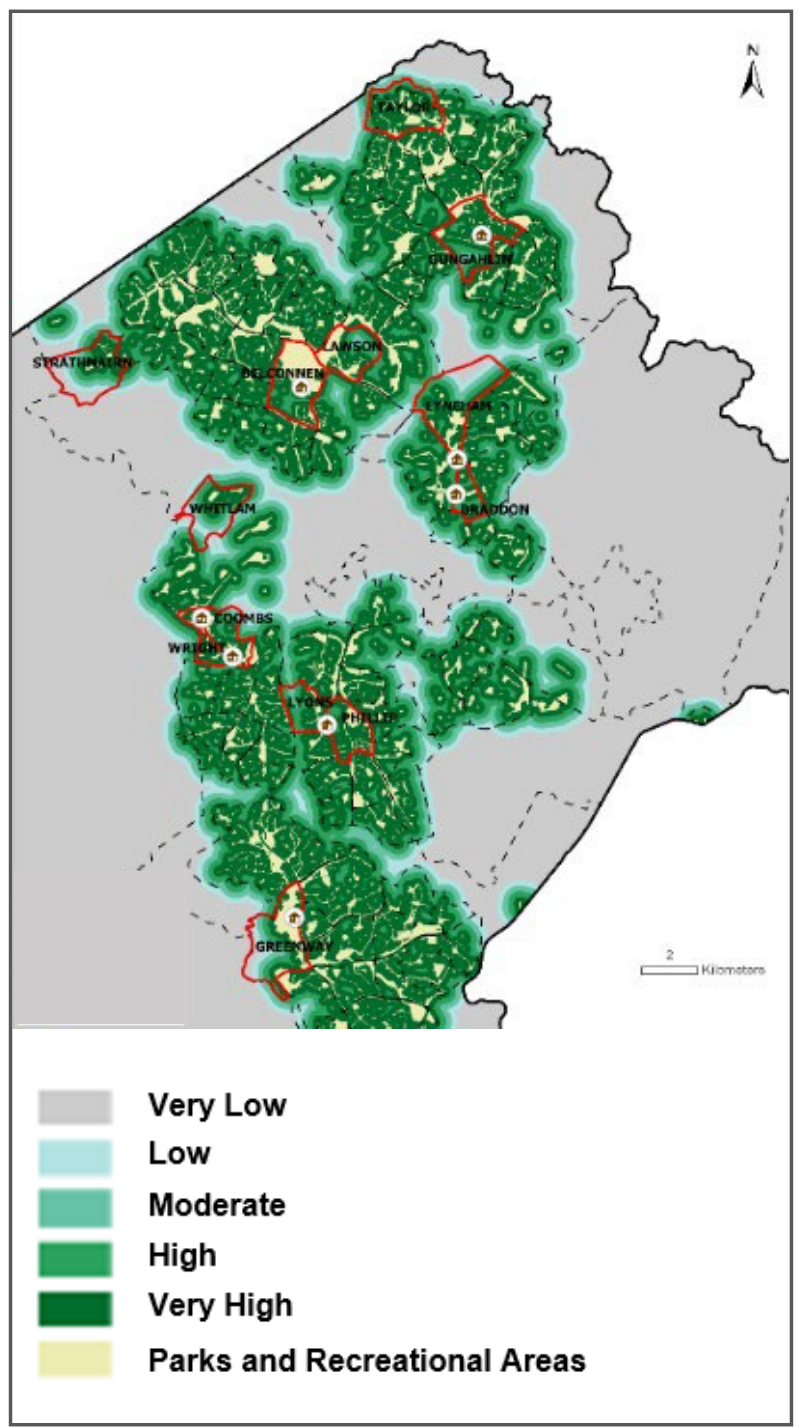

Figure 6: Zoning mapping result

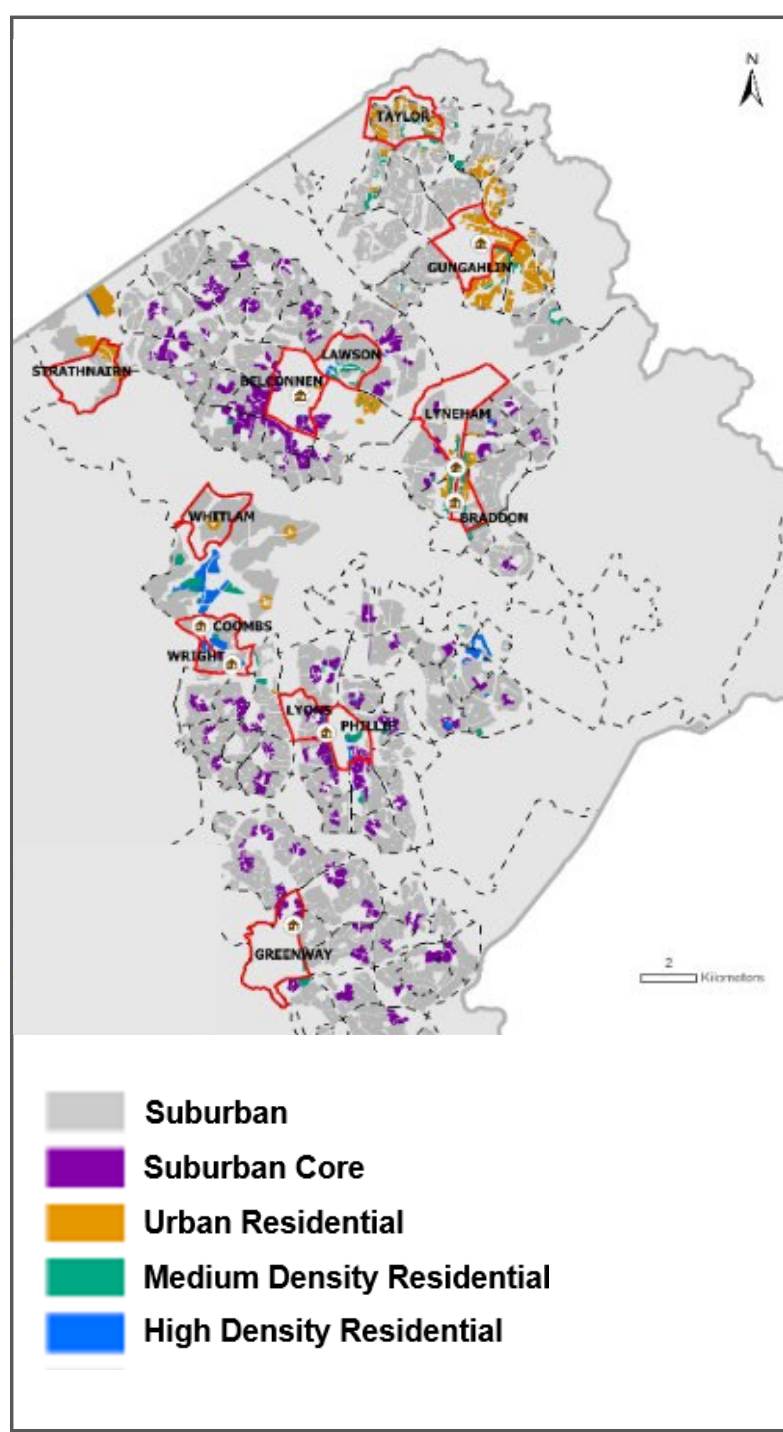

Figure 7: Final IZ land allocation map

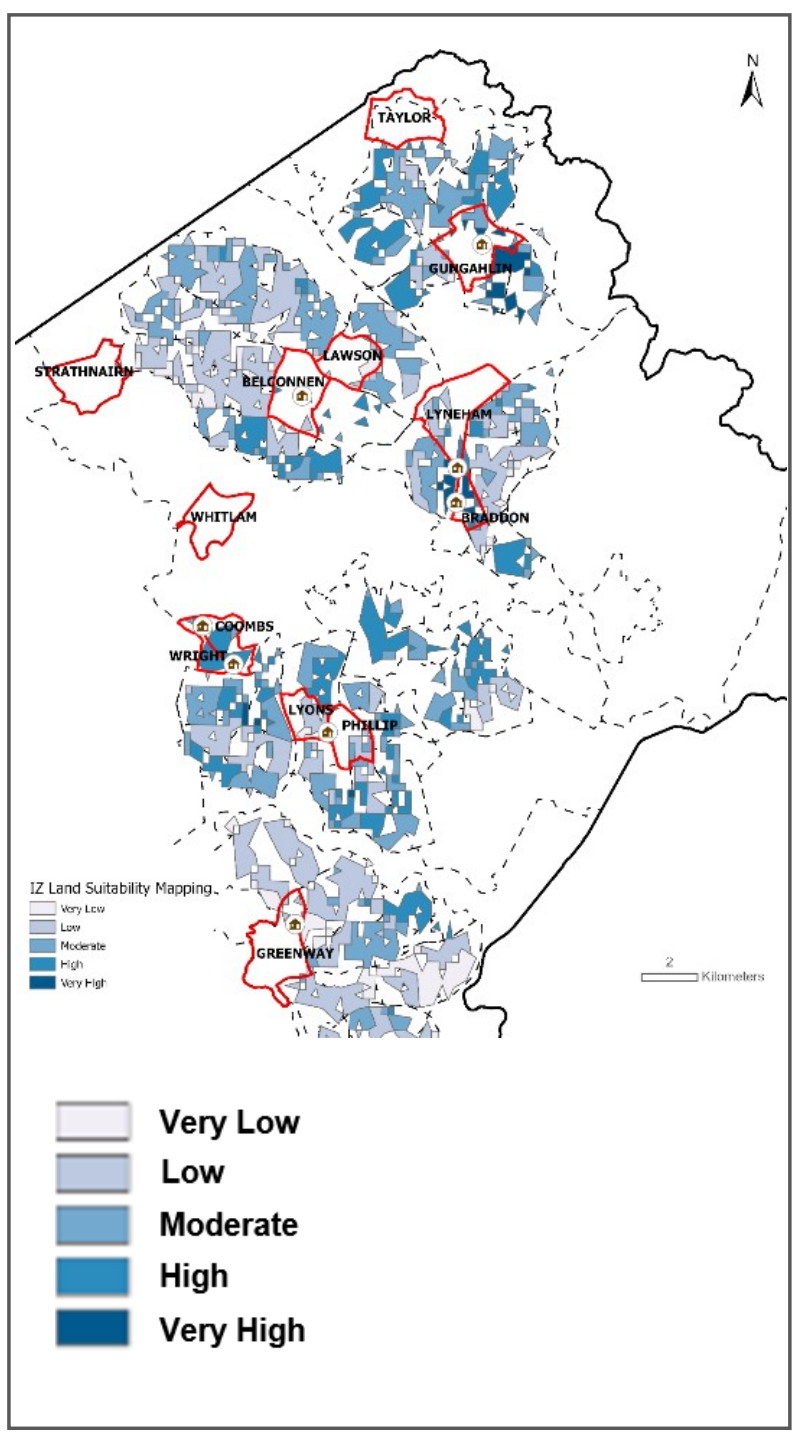




\section{Discussion}

\section{IZ housing targets and deliveries}

There were 1,346 IZ housing units established in the ACT from 2017 to 2020, approaching its target of 1,353 (see Table 3 ). Therefore, this can be seen as a success considering near-fulfillment of predetermined affordable housing targets. The government's commitment is crucial in this process not only by setting up affordable housing targets but also by facilitating the implementing actions, which are underpinned by the four primary factors.

Firstly, homes and Housing department of ACT Government sets up a clear target for guiding affordable housing provisions, including increasing both affordable housing rentals and affordable housing ownership. The housing target is reviewed by different ministers responsible for programs occurring in urban renewal precincts, areas outsidean urban renewal precinct, and new suburbs, respectively. These targets are given legal status and disclosed on the government's website annually.

Secondly, there is a strong statutory mechanism to assist the implementation of affordable housing targets. The annual housing targets are declared through the legalinstrument City Renewal Authority and Suburban Land Agency (Housing Target) Determination under the City Renewal Authority and Suburban Land Agency Act 2017ACT, which is dedicated legislation to assist the affordable home delivery. Also, two housing agencies, the City Renewal Authority and Suburban Land Agency are established under the Act. One of their major functions is to support inclusive communities to meet affordable housing targets in both inner-city areas and suburbs.

Thirdly, an affordable housing legal framework coupled with an appropriate governance arrangement facilitates the implementation process. There is an identified public- private partnership towards providing IZ communities; public land release combined with private development is the primary delivery form. A range of inclusionary zoning provision incentives for private sectors is explored, such as lease variation charge remissions and planning controls.

Finally, diverse funding models improve the viability of the $\mathrm{IZ}$ program. In addition to two IZ planning incentives, an investigation of alternative financing models is also undertaken.

Although a relatively large number of $I Z$ homes have been established in ACT, the capacity to meet affordable housing needs remains in question. Particularly, there were almost 8,000 households who spent more than 30 percent of their income on the private rental market (ACT Government 2018), indicating a relatively large demand for affordable housing. By contrast, only a total number of 1,346 IZ housing units have been delivered in the past three years. It would therefore be unwise to rely entirely on IZ to address the housing market deficiencies caused by multiple factors often exceeding the state management capacity, such as demographic trends, economic environment, housing financialization, and housing and land supply dynamics. Nonetheless, the research identified a significant role of IZ in terms of providing affordable housing, and it should be incorporated into governments' housing policy package.

\section{Comparison of IZ suitability study results and current IZ program}

The final IZ land allocation map demonstrates a relatively fragmented land distribution character (see Figure 7). This possibly links to the existing residential living pattern (see Figure 6) segregated by parks and recreational areas (see Figure 5). In addition, the difference in the IZ suitability scores is more related to the attributes of socioeconomic status and access to public transit. Overall, most IZ housing units fall in low or very low IZ land suitability categories, indicating the need for improving affordable housing quality. 
The overall low IZ land suitability for the current IZ homes may be subject to the following reasons:

- Affordable housing targets are mostly achieved through the Land release program, which can be detected from a high overlap between newly released land and IZ project locations (ACT Government 2019). To be sure, the program is featured with greenfield land supply. Specifically, a "greenfield land supply pipeline" scheme is used to assess suitable broadacre and rural land on the city fringe for possible urban expansion. For instance, there were 8,830 dwelling sites with appropriate zoning in greenfield in the financial year of 2019 to 2020, and 2501 dwelling sites fell into "developers' pipeline" being either completed, under construction or vacant(ACT Government 2020). IZ dwellings are likely to be the end products of the landreleased program being established by developers.

- Two IZ neighbourhoods with the highest IZ land suitability scores are delivered in the urban renewal precinct under the Commonwealth Government's Asset Recycling Initiative (ARI). This initiative offers 15 percent additional payment from the Federal government, which is used to fund ACT's light rail network when selling the state's assets (ACT Government \& City Renewal Authority n.d.). The Territory (State) Government can also sell former underutilized government buildings and public housings to private sectors and allow redevelopment. As for the Braddon IZ program, 80 affordable units in Block 2 Section 8 are developed under the Asset Recycling initiative (ACT Government \& City Renewal Authority n.d.). However, thepublic housing in the urban renewal precinct are relocated elsewhere. Overall, delivering affordable housing in high IZ land suitable areas, such as inner-city suburbs, has faced more challenges. Whereas the federal government's funding coupled with the trade-off between the state government and private developers allows an improved IZ project viability. Notwithstanding, alternative assistance schemes from the Commonwealth need to be explored with an end of the Asset Recycling Initiative in 2019.

- Development cost is likely to be one of the most determinant factors when allocating IZ homes, which is inherently rooted in neoliberalism traditions. Based on ACT Government's land and property report (ACT Government 2020), there is a perceived low development cost in greenfield sites. A relatively large land acquisition cost gap at around $20 \%$ for single blocks between new IZ suburbs and average urban suburbs can be identified. On the other hand, in the places where a higher land acquisition cost occurs, the multi-unit featured development prevailed.

Based on the research, the affordable housing provision in ACT shows a strong market-oriented character, and development cost control is the dominant consideration behind the IZ program delivery. Where affordable housing is offered in higher $I Z$ land suitability areas, external forces and trade-offs often occur. This is in line with the literature review findings; the affordable housing provision highly relies on private sectors, and the government does not intend to add extra burdens on the developer's side. The consequence is that IZ programs are pushed to the urban fringeor IZ families must live in a smaller space. Nevertheless, an overall low IZ land suitability for the current $\mathrm{IZ}$ projects is the case.

There are three limitations raised in this research. Firstly, ACT's new housing strategy started in 2018, which is still in its infancy. Thus, it may be too soon to draw a conclusion. Secondly, there is an opportunity to incorporate stakeholders' views in the rating of IZ land suitability criteria through in-field surveys or workshops. Lastly, one of the assumptions for the IZ project with high suitability is better access to the existing transport infrastructure. Whilst transport infrastructure planning sometimes falls behind housing planning.

Nevertheless, this research identified one of the viable strategies for providing IZ housings in more suitable locations is to utilize federal resources while making trade-offs with developers may be 
inevitable. In addition, this research maps the current suitable land for $I Z$ allocation, which can assist the ACT government's decision-makingtowards the future Indicative Land Release Program. By recognizing suitable IZ landsand working with relevant stakeholders, the ACT government is more likely to pull resources together to build up better IZ communities in the future.

\section{Conclusion}

Despite the fulfillment of affordable housing targets, we find relatively low suitability of IZ projects in ACT considering its ability to achieve five selected criteria. Particularly, few IZ projects have been allocated in high socioeconomic neighbourhoods, while new suburbs with IZ projects have low accessibility to the public transport system. This is contrary to the $I Z$ requirements of promoting socioeconomic integration (Ellickson 1980) and locating IZ projects close to transit corridors (CMAP 2021). As for the provision of $I Z$ homes, this relies on private developers who often emphasize moreon profit maximization instead of the public good. The market-based affordable housing provision methodology is potentially problematic as studies have shown a common trend of locating affordable housing units in the urban periphery worldwide, causing poor accessibility to urban services (Zeng et al. 2019). On the bright side, there is a greater opportunity for the state to intervene housing supply in ACT as land release is more directly controlled by the government than elsewhere, in this case by the Suburban Land Agency. This optimistic view in terms of the role of public land agencies in Australia is also held by Gleeson \& Coiacetto (2005). 


\section{References}

ABS. (2016). 1270.0.55.001 - Australian Statistical Geography Standard (ASGS):Volume 1 Main Structure and Greater Capital City Statistical Areas. Retrieved from <https://www.abs.gov.au/ausstats/abs@.nsf/Lookup/by\%20Subject/1270.0.55 .001 July\%202016 Main\%20Features Statistical\%20Area\%20Level\%202\%2 0(SA2) 10014>.

ABS. (2016). Socio-economic indexes for area (SEIFA) 2016. Retrieved from <https://www.abs.gov.au/ausstats/abs@.nsf/mf/2033.0.55.001>.

ABS. (2021). ACT employment sector. Retrieved from <https://www.abs.gov.au/statistics/labour/employment-and- unemployment/labour force-australia-detailed/mar-2021\#data-download>.

ABS. (2021). National, state and territory population. Retrieved from <https://www.abs.gov.au/statistics/people/population/national-state-and-territorypopulation/latest-release>.

ABS. (2021). Residential Property Price Indexes: Eight Capital Cities. Retrieved from $<$ https://www.abs.gov.au/statistics/economy/price-indexes-and- inflation/residentialproperty-price-indexes-eight-capital-cities/latest-release>.

ACT Government \& City Renewal Authority. (n.d.). Asset Recycling Initiative Program. Retrieved from <https://www.act.gov.au/cityrenewal/places/northbourne-avenue/cityand- gateway-draft-urban-strategy>.

ACT Government. (2008). Territory Plan 2008. Retrieved from <https://www.legislation.act.gov.au/ni/2008-27/Current>.

ACT government. (2015). Building an integrated transport network - active travel. Retrieved from < https://www.transport.act.gov.au/_data/assets/pdf_file/0006/1247064/Active -Travel-framework-ACCESS.pdf>.

ACT Government. (2018). ACT housing strategy. Retrieved from <https://www.act.gov.au/_data/assets/pdf_file/0004/1265638/ACT-Housing-Strategy2018.pdf>.

ACT Government. (2018). Indicative Land Release Program 2019-20 to 2022-23. Retrieved from <https://www.planning.act.gov.au/_data/assets/pdf_file/0008/1370537/2019-20to-2022-23-Indicative-Land-Release-Program-Land-Release-Maps.pdf>.

ACT Government. (2020). ACT housing strategy implementation plan. Retrieved from $<$ https://www.act.gov.au/_data/assets/pdf_file/0006/1265640/ACT- Housing-Strategy2020-Implementation-Plan.pdf>.

ACT government. (2020). ACT housing strategy year 2 report card. Retrieved from

< https://www.act.gov.au/_data/assets/pdf_file/0007/1696984/act-housing- strategyyear-2-report-card.pdf>.

ACT Government. (2020). ACT land and property report - January to June 2020half year report. Retrieved from <https://www.planning.act.gov.au/ data/assets/pdf_file/0003/1754139/2020- Jan-Jun-ACT-Land-and-Property-ReportACCESS.pdf>.

AHURI. (2017). Understanding Inclusionary zoning. Retrieved from <AHURI -Understanding Inclusionary zoning>.

Amirtahmasebi, R., Orloff, M., \& Wahba, S. (2015). Inclusionary Zoning. Retrievedfrom <https://urban-regeneration.worldbank.org/node/46>.

APA. (2021). Promote Inclusionary Growth, Retrieved from < https://www.planning.org/home/action/inclusionary/>.

Austin, P.M., Gurran, N., \& Whitehead, C.M.E. (2014). Planning and affordable housing in Australia, New Zealand and England: common culture; different mechanisms, Journal of housing and the built environment, 29 (3), 455-472. DOI: 
https://doi.org/10.1007/s10901-013-9356-3

Beer, A., Kearins, B., \& Pieters, H. (2007). Housing affordability and planning inAustralia: The challenge of policy under neo-liberalism, Housing studies, 22(1), 11-24. DOI: $10.1080 / 02673030601024572$

Calder, V.B. (2017). Zoning, land-use planning, and housing affordability. Retrievedfrom < https://www.cato.org/policy-analysis/zoning-land-use-planning- housingaffordability>. CMAP. (2008). Inclusionary Zoning Strategy Report. Retrieved from

$<$ https://www.cmap.illinois.gov/about/2040/supporting-materials/process- archive/strategypapers/inclusionary-zoning>. Dawkins, C., Jeon, J.S., \& Kanaap, G. (2017). Creating and Preserving AffordableHomeownership Opportunities: Does Inclusionary Zoning Make Sense, Journal of Planning Education and Research, 37(4), 444-456.

DOI:10.1177/0739456X16659763

Dodson, J. (2010). In the Wrong Place at the Wrong Time? Assessing some Planning, Transport and Housing Market Limits to Urban ConsolidationPolicies, Urban Policy and Research, 28(4), 487-504. DOI: 10.1080/08111146.2010.517158

Ellickson, R. C. (1980). The irony of inclusionary zoning. S. Cal. I. Rev., 54, 1167.

EPSDD. (2007), Previous policy: ACT Affordable Housing Action Plan 2007-2017.Retrieved from <https://www.planning.act.gov.au/urban-renewal/affordable- housing/previouswork>.

EPSDD. (2021). Affordable Home Purchase. Retrieved from $<$ https://www.planning.act.gov.au/urban-renewal/affordable- housing/affordablehome-purchase>.

Evans, A.W. (2008). Economics and land use planning, John Wiley \& Sons.

Fernandez, M.A., \& Martin, S.L. (2020). Staged implementation of inclusionary zoning as a mechanism to improve housing affordability in Auckland, New Zealand, International Journal of Housing Markets and Analysis, 13(4), 617- 633. DOI: https://doi.org/10.1108/IJHMA-11-2019-0114

Glaeser, E. (2014). Land use restrictions and other barriers to growth. Cato Institute,265-278.

Gleeson, B., \& Coiacetto, E. (2005). Public land agencies in Australia: the key to positive planning. Urban Research Program Research Paper, 5, 8-13.

Gurran, N., \& Phibbs, P. (2015). Are Governments Really Interested in Fixing theHousing Problem? Policy Capture and Busy Work in Australia, Housing Studies, 30(5), 711729. DOI: $10.1080 / 02673037.2015 .1044948$

Gurran, N., \& Whitehead, C. (2011). Planning and Affordable Housing in Australiaand the UK: A Comparative Perspective, Housing Studies, 26(7-8), 1193- 1214. DOI: 10.1080/02673037.2011.618982

Gurran, N., Gilbert, C., Kenneth, D.G., Nouwelant, R.V.D., James, A., \& Phibbs,

P. (2018). Supporting affordable housing supply: inclusionary planning in newand renewing communities.

Gurran, N., Milligan, V., Baker, D., Bugg, L., \& Christensen, S. (2008). New directions in planning for affordable housing: Australian and international evidence and implications. Hickey, R., Sturtevant, L., \& Thaden, E. (2014). Achieving lasting affordability through inclusionary housing. Cambridge, MA: Lincoln Institute of Land Policy.

HUD. (2005). Why Not in Our Community? Removing Barriers to Affordable Housing, an Update to the Report of the Advisory Commission on RegulatoryBarriers to Affordable Housing. Retrieved from <https://www.huduser.gov/Publications/pdf/wnioc.pdf>.

InclusionaryHousing.Org. (2019). How does Inclusionary Housing Work. Retrieved from $<$ How Does Inclusionary Housing Work?>.

Javadian, M., Shamskooshki, H., \& Momeni, M. (2011). Application of sustainable urban development in environmental suitability analysis of educational land use by using AHP and GIS in Tehran, Procedia Engineering, 21(1), 72-88. DOI: https://doi.org/10.1016/j.proeng.2011.11.1989

Kautz, B.E. (2001). In defense of inclusionary zoning: Successfully creatingaffordable housing, 
USFL Rev., 36: 971.

Kittelson \& Associates, United States. Federal Transit Administration, TransitCooperative Research Program, \& Transit Development Corporation. (2003). Transit capacity and quality of service manual (Vol. 42). Transportation Research Board.

Kontokosta, C.E. (2014). Mixed-income housing and neighborhood integration: evidence from inclusionary zoning programs, Journal of Urban Affairs, 36(4), 716-741. DOI: https://doi.org/10.1111/juaf.12068

Levy, D.K., McDade, Z., \& Dumlao, K. (2010). Effects from living in mixed-incomecommunities for low-income families, Urban Institute.

Lipman, B.J., (2006). A Heavy Load: The Combined Housing and TransportationBurdens of Working Families, Washington, DC: Center for Housing Policy.

Liu, R., Zhang, K., Zhang, Z., \& Borthwick, A.G.L. (2014). Land-use suitabilityanalysis for urban development in Beijing, Journal of Environmental Management, 145(1), 170-179. DOI: https://doi.org/10.1016/j.jenvman.2014.06.020.

Ludwig, J., Duncan, G.J., Gennetian, L.A., Katz, L.F., Kessler, R.C., Kling, J.R., \& Sanbonmatsu, L. (2013). Long-term neighborhood effects on low-incomefamilies: Evidence from Moving to Opportunity, American economic review, 103(3), 226-231. DOI: 10.1257/aer.103.3.226 Mah, J. (2009). Can Inclusionary Zoning Help Address the Shortage of AffordableHousing in Toronto? Ottawa, Canadian Policy Research Networks Incorporated.

Malczewski, J. (2004). GIS-based land-use suitability analysis: a critical overview, Progress in Planning, 62(1), 3-65. DOI: https://doi.org/10.1016/j.progress.2003.09.002

Mazzulla, G., \& Eboli, L. (2006). A service quality experimental measure for publictransport.

Milligan, V., Phibbs, P., Fagan, K., \& Gurran, N. (2004). A practical framework forexpanding affordable housing services in Australia: learning from experience.Retrieved from http://www.ahuri.edu.au/publications/projects/p60191.

Mukhija, V., Das, A., Regus, L., \& Tsay, S.S. (2015). The Tradeoffs of InclusionaryZoning: What Do We Know and What Do We Need to Know, Planning Practice \& Research, 30(2), 222-235. DOI: https://doi.org/10.1080/02697459.2015.1008793

Murdoch, J., \& Abram, S. (2017). Rationalities of planning: development versusenvironment in planning for housing, Taylor \& Francis.

NAHB. (2019). Inclusionary Zoning, National Association of Home Builders. Retrieved from $<$ https://www.nahb.org/advocacy/industry-issues/land-use- 101/state-and-localhousing-affordability/inclusionary-zoning>.

National shelter. (2019). 190325 Inclusionary Zoning Report V6 Final. Retrieved from $<$ https://www.shelterwa.org.au/wp-content/uploads/2019/10/Inclusionary- ZoningReport-National-Shelter.pdf>.

Nyerges, T., Jankowski, P., Nyerges, T., \& Jankowski, P. (2010). Making choicesabout GISbased multicriteria evaluation, Guilford Press New York: 136-159.

Oxley, M. (2004). Economics, planning and housing, Basingstoke: PalgraveMacmillan.

Property Council of Australia. (2020). Walkable neighbourhoods. Retrieved from $<$ https://www.propertycouncil.com.au/Web/Content/News/QLD/2020/Walkable Neighbourhoods.aspx>.

Rothwell, J. (2012). Housing costs, zoning, and access to high-scoring schools,Washington, DC: Brookings Institution.

Rowley, S. (2012) Housing affordability, housing stress and household wellbeing inAustralia, Australian Housing and Urban Research Institute.

Schwartz, H.L., Ecola, L., Leuschner, K. J., \& Kofner, A. (2012). Is Inclusionary Zoning Inclusionary? A Guide for Practitioners, Technical Report, RAND Corporation, Santa Monica, CA.

Stone, M.E. (2006). What is housing affordability? The case for the residual incomeapproach, Housing Policy Debate, 17(1), 151-184. DOI: https://doi.org/10.1080/10511482.2006.9521564

Sturtevant, L.A. (2016). Separating Fact from Fiction to Design Effective Inclusionary Housing 
Programs, Washington, DC: Center for Housing Policy.

Suburban Land Agency. (2018). Annual Report 2017-18. Retrieved from <Suburban Land Agency Annual Report 2017-18 (act.gov.au)>.

Suburban Land Agency. (2019). Annual Report 2018-19. Retrieved from <Suburban Land Agency Annual Report 2018-19 (act.gov.au)>.

Suburban Land Agency. (2020). Annual Report 2019-20. Retrieved from <Suburban Land Agency Annual Report 2019-20 (act.gov.au)>.

Sugiyama, T., Francis, J., Middleton, N.J., Owen, N., \& Giles-Corti, B. (2010). Associations between recreational walking and attractiveness, size, andproximity of neighborhood open spaces, American journal of public health, 100(9), 1752-1757. DOI:https://ajph.aphapublications.org/doi/abs/10.2105/AJPH.2009.182006

Thaden, E., \& Wang, R. (2017). Inclusionary housing in the United States:Prevalence, impact, and practices, JSTOR.

Thomas, M. (2016). Housing affordability in Australia. Retrieved from < Housingaffordability in Australia - Parliament of Australia (aph.gov.au)>.

Transport Canberra. (2020). Bus Stops - New Network July 2020. Retrieved from $<$ https://www.data.act.gov.au/Transport/Bus-Stops-New-Network-July- 2020/vdh8ug3k>.

Tuller, D. (2018). Housing and health: The role of inclusionary zoning, Health Affairs.

Wetzstein, S. (2017). The global urban housing affordability crisis, Urban Studies, 54(14), 3159-3177. DOI: https://doi.org/10.1177\%2F0042098017711649

White, M., \& Allmendinger, P. (2003). Land-use planning and the housing market: A comparative review of the UK and the USA, Urban Studies, 40(5-6), 953-972. DOI: https://doi.org/10.1080\%2F0042098032000074263

Williams, P. (2000). Inclusionary zoning and affordable housing in Sydney, UrbanPolicy and Research, 18(3), 291-310. DOI: https://doi.org/10.1080/08111140008727840

Worthington, A. C. (2012). The quarter century record on housing affordability,affordability drivers, and government policy responses in Australia.

International Journal of Housing Markets and Analysis, 5(3), 235-252. DOI: https://doi.org/10.1108/17538271211243580

Yang, Y., \& Diez-Roux, A.V. (2012). Walking distance by trip purpose and population subgroups, American journal of preventive medicine, 43(1), 11-19. DOI: https://doi.org/10.1016/j.amepre.2012.03.015

Zeng, W., Rees, P., \& Xiang, L. (2019). Do residents of Affordable Housing Communities in China suffer from relative accessibility deprivation? A casestudy of Nanjing, Cities, 90(1), 141-156. DOI: https://doi.org/10

\section{Biographical notes}

Shuangshuang Zheng has a Masters of Urban and Regional Planning in the School of Earth and Environmental Science, Faculty of Science, University of Queensland.

Thomas Sigler is Senior Lecturer in Human Geography, School of Earth and Environmental Science, Faculty of Science, University of Queensland. 
Journal of Social Inclusion, 10(2), 2019 